\title{
Improvements in the fluorimetric determination of the RNA and DNA content of individual marine fish larvae
}

\section{Catriona Clemmesen*}

Institut für Hydrobiologie und Fischereiwissenschaft der Universität Hamburg, Olbersweg 24, D-22767 Hamburg, Germany

\begin{abstract}
The RNA/DNA ratio is a useful indicator of the nutritional condition of fish larvae. The presented analytical procedure is an improvement of Clemmesen's (Meeresforschung 32: 134-143, 1988) methodology which involves purification of fish larvae tissue homogenates and subsequent fluorescence-photometric measurements using specific nucleic acid dyes. The modifications concern the homogenization and nucleic acid extraction procedures. A 'shaking mill' was compared to a potter Elvehjem microhomogenizer and a reduction in the washing and purification steps was achieved. Treatment of samples with ribonuclease $\mathrm{A}$ and subsequent fluorescence measurement using ethidium bromide was given preference compared to the DNA-bisbenzimidazole determinations due to problems arising from high self-fluorescence of the samples and the influence of 'quenching' substances disturbing the DNA-bisbenzimidazole determinations. Different RNase concentrations and their influences on RNA and DNA were checked. Recovery rates of standard RNA and DNA 'spikes' were determined. Fish larvae samples were analysed with the previous and the improved modified procedure and a correction factor to compare results measured with the 2 procedures was calculated. With the presented method the physiological condition of individual larvae and the amount of variability can be determined.
\end{abstract}

\section{INTRODUCTION}

Nucleic acids play a major role in growth and development. The amount of DNA, the carrier of genetic information, is quasi-constant in somatic tissues and tissue concentrations therefore reflect cell numbers (Regnault \& Luquet 1974, Dortch et al. 1983). The amount of RNA in the cell is directly proportional to the amount of protein synthesis occurring. The relationship between RNA and DNA is an index of the cell's metabolic intensity and has been used to measure recent growth in fishes (see review by Bulow 1987). It has proven a useful indicator of nutritional condition as shown in several larval fish studies (Buckley 1979, 1980, 1984, Martin et al. 1985, Fukuda et al. 1986,

- Present address: Institut für Meereskunde an der Universität Kiel, Düsternbrooker Weg 20, D-24105 Kiel, Germany
Buckley \& Lough 1987, Clemmesen 1987, Raae et al. 1988, Robinson \& Ware 1988, Westerman \& Holt 1988).

Most previous studies measuring RNA/DNA ratios in larval fish used a method which required a minimum of $800 \mu \mathrm{g}$ dry wt sample ${ }^{-1}$ (Buckley 1979). Thus samples had to be pooled for analysis and estimates of the individual variability in RNA/DNA ratios were impossible. But such estimates could be essential for detecting starving individuals in the field to determine whether starvation plays a major role in the recruitment process. Therefore a highly sensitive fluorimetric method, allowing the determination of the RNA/DNA ratios of individual larvae, was developed (Clemmesen 1988). After some years of experience with the RNA/DNA fluorescence technique, I present certain improvements and simplifications that chiefly concern the method of extracting the nucleic acids and the fluorimetric determination of RNA and DNA. 


\section{MATERIALS AND METHODS}

Chemicals. All chemicals used in the procedures were analytical grade. Ethidium bromide (EB) and ribonuclease A were obtained from Serva (Heidelberg, Germany). Ribonuclease A was dissolved in Tris- $\mathrm{HCl}$ buffer ( $\mathrm{pH} 7.5$ ) at a final concentration of $0.01 \mathrm{mg} \mathrm{ml}^{-1}$ heated to $100^{\circ} \mathrm{C}$ for $15 \mathrm{~min}$ to destroy possibly present DNase (Maniatis et al. 1982). After cooling to room temperature the solution was split into aliquots and stored at $-20^{\circ} \mathrm{C}$ until further use. Lambda DNA and ribosomal RNA (16s, 23s) were purchased from Baehringer (Mannheim, Germany). Bisbenzimidazole (Hoechst 33258) was obtained from Sigma Chemicals (Germany) and sodium dodecyl sulfate (SDS) from Merck (Darmstadt, Germany).

Extraction of nucleic acids. The aim was to modify the technique to reduce the number of necessary purification steps and to avoid the time-consuming manual procedure for homogenizing individual larvae. In the modified procedure the manual homogenisation is replaced by using a commercially available shaking mill (Retsch Type MM-2, Germany) which can hold 10
Eppendorf capped vials at a time. A single fish larva is put into a vial containing $0.4 \mathrm{ml}$ of Tris- $\mathrm{NaCl}$ buffer (0.05 M Tris, $0.1 \mathrm{M} \mathrm{NaCl}, 0.01 \mathrm{M}$ EDTA and $2 \%$ SDS adjusted to $\mathrm{pH} 8.0$ with $\mathrm{HCl}$ ) and glass beads (diameter 0.2 and $2 \mathrm{~mm}$ ). The glass beads are moved rapidly in the solution and disrupt the larval tissue. A shaking time of $15 \mathrm{~min}$ is sufficient for complete homogenisation of the tissue. All steps are carried out on ice to minimize the possible effect of DNases and RNases.

For purification of the nucleic acid solutions, 2 washes with Tris-NaCl-saturated phenol and chloroform/isoamylalcohol $(24: 1 \mathrm{v} / \mathrm{v})$ were carried out as shown in Fig. 1. The purity of the solution was evaluated by separating the purified larval nucleic acids by agarose gel electrophoresis using $0.8 \%$ agarose in Tris-EDTAsodium acetate buffer. Molecular markers Hind IIIdigested lambda phage DNA fragments and ACCIfragments were run in parallel on every gel. To visualize the nucleic acids in the gels they were stained with EB solutions (Maniatis et al. 1982). To evaluate losses of nucleic acids occurring in the extraction procedure a known amount of commercially available standard DNA and RNA ('spike') was added to

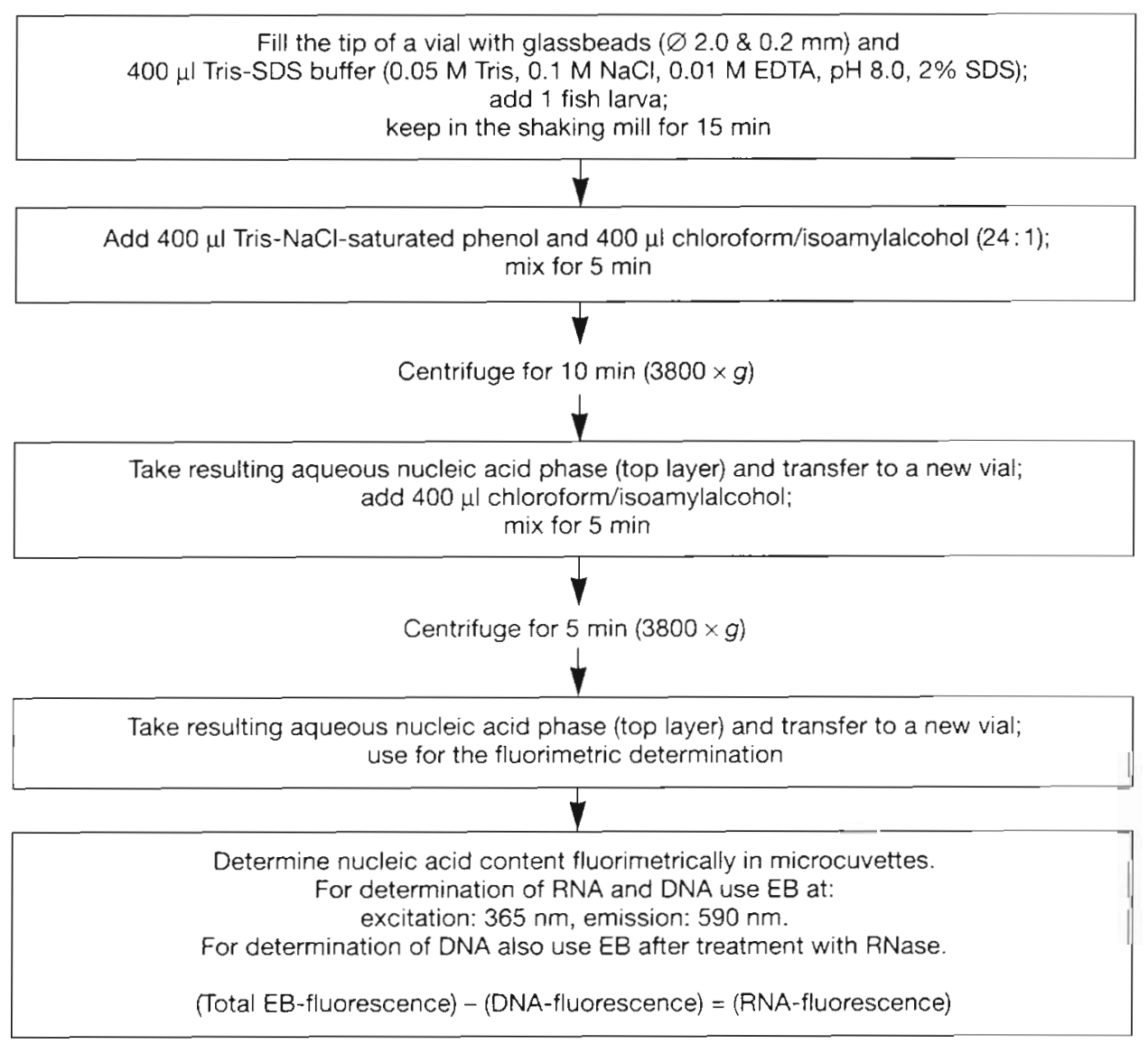

Fig. 1. Flowchart of the improved and modified analytical procedure 
24 larval herring homogenates prior to the extraction procedure. An aliquot of the herring homogenate without a 'spike' as well as the RNA and DNA standards were also assayed.

The optimum concentration of RNase A necessary to digest the larval RNA completely without destroying the existing DNA had to be determined. Standard nucleic acid solutions were incubated with 5 different RNase concentrations $\left(10,15,25,50,100 \mu \mathrm{g} \mathrm{ml} \mathrm{m}^{-1}\right)$ at $37^{\circ} \mathrm{C}$ for $30 \mathrm{~min}$ and fluorimetrically determined.

To compare results determined with the previous procedure (Clemmesen 1988) and with the modified methodology, intercalibration tests were performed. Aliquots of a pooled herring larvae homogenate were treated with the old and the new modified extraction and measuring procedure.

Fluorescence assay. The fluorimetric assay of DNA and RNA depends on the use of specific fluorophors which react with nucleic acids and result in an increase in fluorescence intensity. The fluorophor EB was used to determine both RNA and DNA (Le Pecq \& Paoletti 1966, Karsten \& Wollenberger 1972, 1977, Prasad et al. 1972, Beers \& Wittliff 1975). Bisbenzimidazole, a DNAspecific fluorescence dye, has been used to measure DNA content in cell and tissue homogenates (Brunk et al. 1979, Cesarone et al. 1979, Labarca \& Paigen 1980, DeFlaun et al. 1986). My earlier method relied on EB and bisbenzimidazole. But because data obtained using the bisbenzimidazole technique were difficult to reproduce due to problems with self-fluorescence, I developed an improved method which replaces bisbenzimidazole with EB. First the fluorescence of DNA and RNA was measured using $0.6 \mathrm{ml}$ of the sample after adding $0.05 \mathrm{ml}$ of the EB stock solution $\left(0.1 \mathrm{mg} \mathrm{ml}^{-1}\right)$. Secondly an aliquot of the sample was treated with RNase incubated at $37^{\circ} \mathrm{C}$ for $30 \mathrm{~min}$ and measured fluorimetrically using EB. Measurements were performed with a Kontron spectrofluorometer (SFM 25) at $30^{\circ} \mathrm{C}$ exciting at $365 \mathrm{~nm}$, and reading the emission at $590 \mathrm{~nm}$. The fluorescence due to RNA can then be calculated as the difference between total fluorescence (RNA and DNA) and fluorescence after ribonuclease treatment, which is assumed to be due only to DNA. For further details on the fluorimetric determination see Clemmesen (1988).

Herring larvae aged 9 to $65 \mathrm{~d}$ were reared under laboratory conditions as described by Clemmesen (1987). Larval material was used for evaluating the influences of different analytical steps on the nucleic acids.

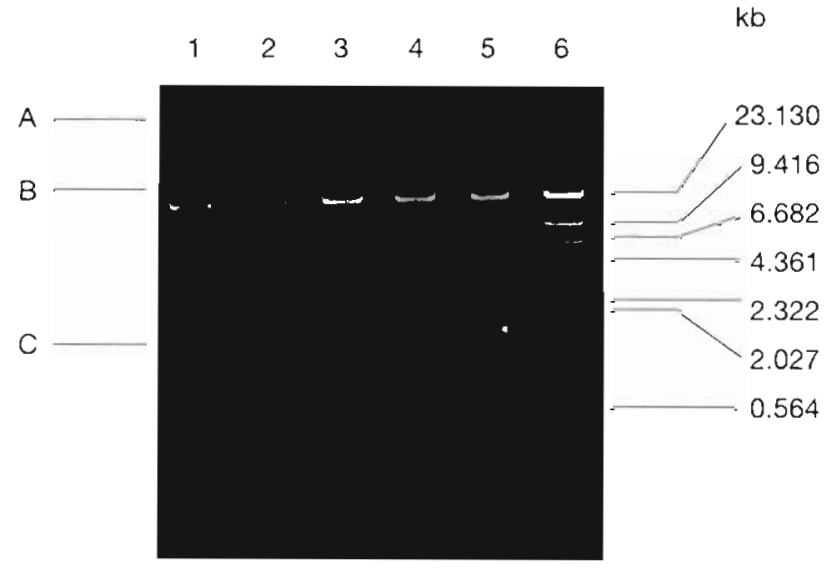

Fig. 2. Agarose gel electrophoresis of purified DNA and RNA extracted from individual herring larvae. Lanes 1 to 5 give DNA bands $(B)$ and RNA bands $(C)$ of individual larvae. Lane 6 shows the molecular weight standard (Lambda DNA cut with the restriction enzyme Hind III and ACC I). The values for molecular weight are given in kilobases. (A) indicates the start-slots of the samples

\section{RESULTS}

The modified analytical procedure resulted in high molecular weight, fairly undegraded DNA and defined RNA subunits as shown by agarose gel electrophoresis (Fig. 2). The influence of the new modified purification procedure on larvae nucieic acids in comparison to the old methodology was checked by determining the RNA and DNA content of aliquots of pooled herring larvae samples. Table 1 compares the results of the RNA and DNA determinations with the 1988 purifica-

Table 1 Comparison of 2 different nucleic acid purification procedures for determining RNA and DNA content of larval fish. Aliquots of a pooled herring larvae sample were fluorimetrically analyzed with bisbenzimidazole (1988 method) and ethidium bromide (modified method). $x$ : mean, $s_{x}$ : standard deviation, $V_{x}$ : coefficient of variability in $\%$

\begin{tabular}{|c|c|c|c|c|c|c|}
\hline & \multicolumn{3}{|c|}{1988 procedure } & \multicolumn{3}{|c|}{ Modified procedure } \\
\hline & $\begin{array}{l}\mu \mathrm{g} \text { DNA } \\
\text { larva }^{-1}\end{array}$ & $\begin{array}{l}\mu \mathrm{g} R \mathrm{RA} \\
\operatorname{larva}^{-1}\end{array}$ & RNA/DNA & $\begin{array}{c}\mu \mathrm{g} \text { DNA } \\
\text { larva }^{-1}\end{array}$ & $\begin{array}{c}\mu \mathrm{g} \text { RNA } \\
\text { larva }^{-1}\end{array}$ & RNA/DNA \\
\hline & 1.72 & 6.04 & 3.5 & 3.13 & 8.53 & 2.7 \\
\hline & 2.08 & 6.28 & 3.0 & 2.70 & 8.32 & 3.1 \\
\hline & 2.12 & 6.04 & 2.8 & 2.97 & 7.53 & 2.5 \\
\hline & 1.88 & 6.12 & 3.3 & 2.60 & 8.22 & 3.2 \\
\hline & 2.24 & 6.28 & 2.8 & 2.54 & 8.27 & 3.3 \\
\hline & 2.92 & 6.20 & 2.1 & 2.81 & 8.43 & 3.0 \\
\hline & 2.12 & 5.88 & 2.8 & 3.07 & 7.95 & 2.6 \\
\hline & 2.04 & 5.96 & 2.9 & 2.92 & 7.79 & 2.7 \\
\hline$x:$ & 2.14 & 6.10 & 2.90 & 2.84 & 8.13 & 2.89 \\
\hline$s_{x}:$ & 0.35 & 0.15 & 0.41 & 0.22 & 0.34 & 0.30 \\
\hline$V_{x}:$ & 16.50 & 2.40 & 14.30 & 7.62 & 4.21 & 10.38 \\
\hline \multicolumn{7}{|c|}{ a Source: Clemmesen (1988) } \\
\hline
\end{tabular}




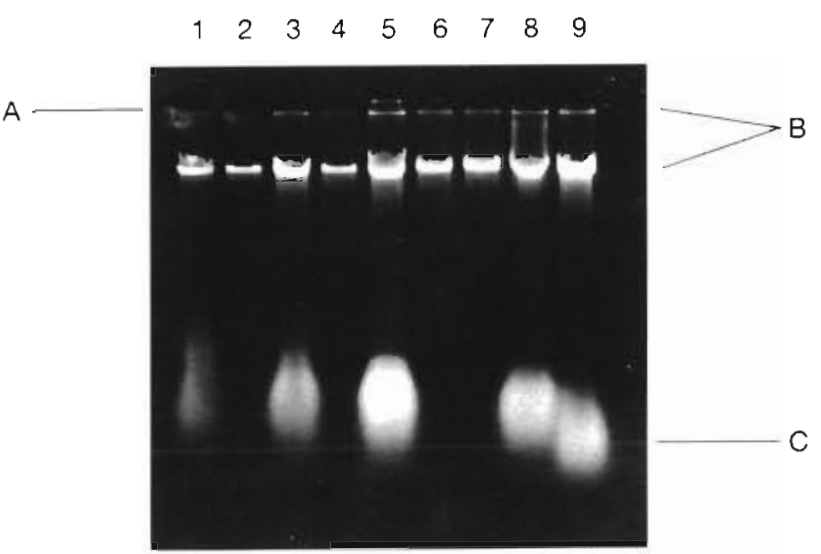

Fig. 3. Agarose gel electrophoresis of purified DNA and RNA samples extracted from individual herring larvae. Lanes $1,3,5,8 \& 9$ show the DNA and RNA bands of the individual larvae. Samples in Lanes 2, 4, 6 \& 7 were treated with RNase.

(A) Start-slot, (B) DNA bands and (C) RNA bands

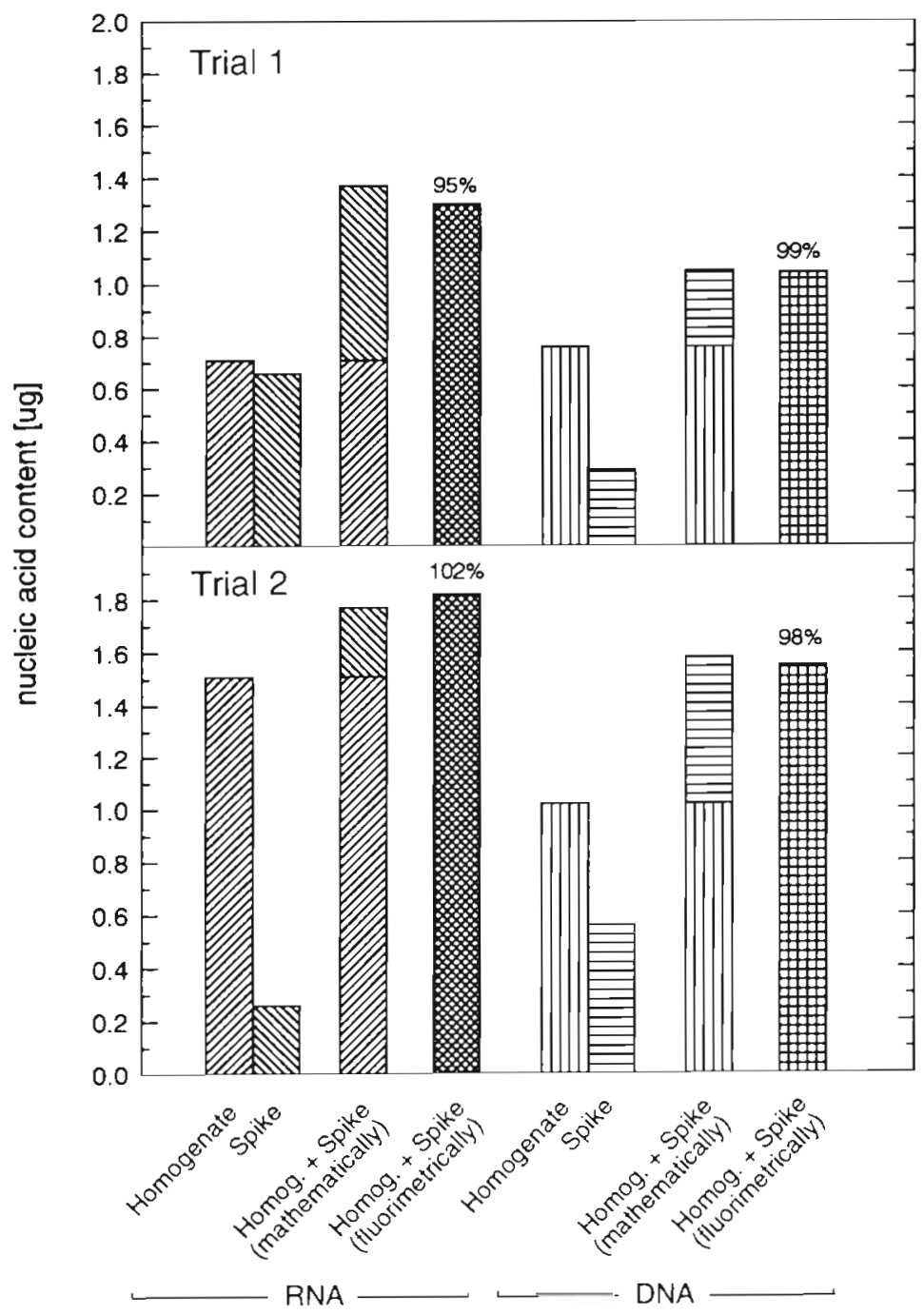

tion procedure and the newly modified assay. Because each phenol/chloroform/isoamylalcohol washing step causes loss of nucleic acids, decreasing the number of steps was expected to improve recovery and lead to a higher RNA and DNA content ( $t$-test, $p<0.05$ ).

In all concentrations used, the RNase completely digested the existing RNA leaving a fluorescence signal in the range of $3 \%$, which resulted from the autofluorescence of the enzyme itself. RNase concentrations of 50 and $100 \mu \mathrm{g} \mathrm{ml}^{-1}$ led to a decrease in the DNA fluorescence signal in the range of 4 to $6 \%$. To avoid loss of DNA material the lowest concentration of RNase $\left(10 \mu \mathrm{g} \mathrm{ml}^{-1}\right)$ was used. Agarose gel electrophoresis of purified nucleic acids from herring larvae was used to further check the ability of RNase to totally digest larval RNA. Samples treated with RNase showed an absence of the RNA band indicating that RNA was completely digested by RNase (Fig. 3).

The extraction procedure led to a recovery rate for 2 trials each of 98 and $99 \%$ for DNA and 102 and $95 \%$ for RNA (Fig. 4).

Comparison of the previously used and the new modified procedure resulted in significantly higher DNA determinations and approximately the same RNA amount (Table 2). This led to lower RNA/DNA ratios. In order to compare data determined with these 2 procedures, the RNA/DNA ratios measured with the new procedure have to be multiplied by a factor of 1.20. The data given in the lower part of Table 2 resulted from RNA and DNA determinations of individual herring larvae from 1 sample group (mean of 3 to 11 ind.). Therefore differences occurring can be due to larval individuality. The calculated correction factor for this procedure (1.24) is comparable with the one derived from the parallel aliquots.

\section{DISCUSSION}

In comparison to conventionally used UVabsorption tests (Buckley 1979) with a threshold of 1 to $2 \mu \mathrm{g}$ DNA or RNA ml ${ }^{-1}$ reflecting a minimum larval material of $0.8 \mathrm{mg}$ dry wt

Fig. 4. RNA and DNA contents of herring larvae homogenates and recovery rates of RNA and DNA calculated from 'spiked' samples. Presented data are means of 12 determinations of aliquots of pooled herring larvae homogenates in both trials. The recovery rates result from comparing the fluorimetrically determined nucleic acid plus 'spike' measurement with the mathematically expected value 
Table 2. RNA and DNA content of aliquots of a pooled herring larvae homogenate (means of 11 parallel determinations of the same homogenate) and from individual herring larvae (means of 3 to 11 parallel determinations of individual larvae from the same sample group) determined with the previous methodology (Clemmesen 1988) and the modified procedure (Fig. 1). $V_{x}$ : coefficient of variability in $\%$

\begin{tabular}{|c|c|c|c|c|c|c|c|c|}
\hline & \multicolumn{3}{|c|}{ Previous methodology } & \multicolumn{3}{|c|}{ Modified methodology } & & \multirow[t]{2}{*}{$\mathrm{A} / \mathrm{B}$} \\
\hline & $\mu \mathrm{g}$ DNA & $\mu \mathrm{g}$ RNA & $\begin{array}{c}\text { RNA/DNA } \\
\text { (A) }\end{array}$ & $\mu \mathrm{g}$ DNA & $\mu \mathrm{g}$ RNA & $\begin{array}{c}\text { RNA/DNA } \\
\text { (B) }\end{array}$ & & \\
\hline \multicolumn{9}{|c|}{ Pooled homogenate } \\
\hline & $3.54 \pm 0.23$ & $5.48 \pm 0.41$ & $1.56 \pm 0.11$ & $4.08 \pm 0.17$ & $5.42 \pm 0.39$ & $1.34 \pm 0.12$ & & 1.16 \\
\hline \multirow[t]{2}{*}{$V_{x}:$} & 6.50 & 7.48 & 7.05 & 4.17 & 7.20 & 9.00 & & \\
\hline & $1.80 \pm 0.13$ & $2.96 \pm 0.29$ & $1.58 \pm 0.15$ & $2.08 \pm 0.07$ & $2.68 \pm 0.24$ & $1.28 \pm 0.13$ & & 1.23 \\
\hline$V_{x}:$ & 7.22 & 9.80 & 9.49 & 3.37 & 9.00 & 10.20 & mean & 1.20 \\
\hline \multicolumn{9}{|c|}{ Individual larvae } \\
\hline & $1.57 \pm 0.07$ & $5.44 \pm 0.83$ & $3.40 \pm 0.49$ & $2.60 \pm 0.31$ & $6.43 \pm 0.83$ & $2.50 \pm 0.25$ & & 1.36 \\
\hline \multirow{2}{*}{\multicolumn{2}{|c|}{$1.70 \pm 0.11$}} & $4.82 \pm 0.85$ & $2.80 \pm 0.36$ & $2.54 \pm 0.17$ & $6.28 \pm 0.68$ & $2.50 \pm 0.22$ & & 1.12 \\
\hline & & & & & & & mean & 1.24 \\
\hline
\end{tabular}

the highly sensitive method using fluorescence dyes allows the determination of $0.1 \mu \mathrm{g}$ DNA or RNA ml${ }^{-1}$ (Clemmesen 1988). The aim in this study was to improve and modify the 1988 method for quantitative determinations of DNA and RNA contents in whole-body homogenates. When using the 1988 procedure on routine assays of hundreds of fish larvae, I obtained unsatisfactory measurements with the bisbenzimidazole determinations. The self-fluorescence of the sample (before the dye is added) was very unstable, reaching values of $40 \%$. Thus DNA determinations were less reliable which also resulted in less reproducible RNA determinations, since both measurements are linked. With EB, self-fluorescence was in the range of 1 to $4 \%$, and was negligible.

The purification procedure for RNA and DNA resulted in high molecular weight DNA and fairly undegraded RNA as seen from agarose gel electrophoresis (Fig. 2) but a certain amount of 'smear' still occurred, indicating that the extracted nucleic acids are not completely pure. In the case of the RNA- and DNA-EB fluorescence, these remaining substances do not cause any problems; the nucleic acid dye complex is stable and gives reproducible results. The DNAbisbenzimidazole complex seems more susceptible to interferences than the nucleic acid-EB complex. Clarke et al. (1989) determined DNA contents in young cuttle fish using bisbenzimidazole and found very variable DNA concentrations. Unexpectedly no significant correlation between DNA content and size of the analysed animals could be determined. Since they used a very insufficient nucleic acid purification procedure, contamination with celi substances other than nucleic acids might have caused problems in determining DNA via bisbenzimidazole accurately. Brunk et al. (1979) described 'quenching' substances (Guiltbault 1973) disturbing the DNA-bisbenzimidazole measurement occurring when crude cell homogenates or lysates were used. However, Cesarone et al. (1979) found very good reproducibility (approximately 5\%) between the DNA-bisbenzimidazole determinations when working with cell cultures or sufficiently purified DNA solutions from rat livers. The necessity of including purification steps into the assay procedure to eliminate the substances causing 'quenching' was also observed by other authors (DeBevoise \& Taghon 1988 , Mordy \& Carlson 1991, McGurk \& Kusser 1992).

Another reason for variable DNA determinations might be due to the specificity of bisbenzimidazole for DNAs rich in dA-dT base pairs (Weisblum \& Haenssler 1974). Depending on the base composition of the DNA, different reactions of DNAs with bisbenzimidazole were found. Concluding, the DNA-bisbenzimidazole measurement should only be used when DNAs from cell cultures or highly purified homogenates are to be analysed. The influence of 'quenching' substances has to be further evaluated before a routine use can be proposed.

In the modified procedure the use of RNase $A$ to digest RNA and the subsequent measurement of the remaining DNA content by EB was given preference due to the problems with bisbenzimidazole described earlier. RNase is widely used (Karsten \& Wollenberger 1972, 1977, Bentle et al. 1981, DeBevoise \& Taghon 1988, Robinson \& Ware 1988) but in some studies the concentration of RNase used might be too high and may affect the amount of DNA present in the sample.

The reduction in number of necessary phenol/ chloroform/isoamylalcohol washing steps gave satisfactory results leading to higher amounts of extracted 
nucleic acids. The nucleic acid purification procedure presented here was applied to laboratory-reared herring larvae (Clemmesen-Bockelmann 1992) and worked efficiently for the size groups 'freshly-hatched' to ca $15 \mathrm{~mm}$ standard length. For larger larvae the buffer volume had to be increased and the phenol washing steps had to be repeated to avoid protein contamination of the nucleic acid solution.

The presented nucleic acid recovery rates were near $100 \%$ and demonstrated that the procedure used is quantitative and protects the nucleic acids. The lower RNA recovery rates indicate that some RNA is lost during the procedure, probably due to the smaller molecular size. The recovery values found in this study are in good agreement with values given by Dagg \& Littlepage (1972) and Prasad et al. (1972) using procedures without purification steps involved. The use of purification steps in this study therefore does not seem to result in significant loss of nucleic acids.

Results of the comparison between the old and the new improved methodology (Table 2) showed that a correction factor has to be applied to compare data derived from the 2 procedures. This indicates that the different procedures used and described in the literature can lead to different results making a direct comparison of data impossible. Therefore a need for standardization of analytical procedures and intercalibration work has to be encouraged. The new modified procedure has been applied to hundreds of laboratory-reared and wild herring larvae to evaluate their nutritional condition and has proven to work efficiently and with high reproducibility (Clemmesen 1989, Clemmesen-Bockelmann 1992, Ueberschär \& Clemmesen 1992).

The analytical procedure described is successful in determining nucleic acid contents of whole body homogenates of individual fish larvae, leading to a better reproducibility and a greater number of larvae analyzed per time unit compared to the previous procedure. Since the nucleic acid content can be used to determine the physiological condition in other marine organisms (Dortch et al. 1983, Ota \& Landry 1984, Wright \& Hetzel 1985, Wang \& Stickle 1986, DeBoise \& Taghon 1988, Anger \& Hirche 1990) the improved analytical procedure should be applicable when only small quantities of tissue material (approximately $25 \mu \mathrm{g}$ dry wt) are available.

Acknowledgements. Part of the study was supported by the Bundesministerium fur Forschung und Technologie grant no. MFE 0541/9. I thank Dr A. Jahns for helpful discussion and running of the gel electrophoresis. Drs K. Tiffert and $T$ Both provided helpful ideas for modifying the procedure. The paper benefited from the comments of 2 anonymous reviewers.

\section{LITERATURE CITED}

Anger, K., Hirche, H.-J. (1990). Nucleic acids and growth of larval and early juvenile spider crab, Hyas araneus. Mar. Biol. 105(3): 403-411

Beers, P. C., Wittliff, J. L. (1975). Measurements of DNA and RNA in mammary gland homogenates by the ethidium bromide technique. Anal. Biochem. 63: 433-441

Bentle, L. A., Dutta, S., Metcoff, J. (1981). The sequential enzymatic determination of DNA and RNA. Anal. Biochem. 116: 5-16

Brunk, C. F., Jones, K. C., James, T. W. (1979). Assay of nanogram quantities of DNA in cellular homogenates. Anal. Biochem. 92: 497-500

Buckley, L. J. (1979). Relationship between RNA/DNA ratio, prey density and growth rate in Atlantic Cod (Gadus morhua) larvae. J. Fish. Res. Bd Can. 36: 1497-1502

Buckley, L. J. (1980). Changes in the ribonucleic acid, deoxyribonucleic acid, and protein content during ontogenesis in winter flounder, Pseudopleuronectes americanus, and the effect of starvation. Fish. Bull. U.S. 77: 703-708

Buckley, L. J. (1984). RNA/DNA ratio: an index of larval fish growth in the sea. Mar. Biol. 80: 291-298

Buckley, L. J., Lough, R. G. (1987). Recent growth, chemical composition and prey field of haddock (Melanogrammus aeglefinus) and cod (Gadus morhua) larvae and post larvae on Georges Bank, May 1983. Can. J. Fish. Aquat. Sci. 44: 14-25

Bulow, F. J. (1987). RNA-DNA ratios as indicators of growth in fish: a review. In: Summerfelt, R. C., Hall, G. E. (eds.) Age and growth in fish. Iowa State University Press, Ames p. $45-64$

Cesarone, C. F., Bolognesi, C., Santi, L. (1979). Improved microfluorometric DNA determination in biological material using 33258 Hoechst. Anal. Biochem. 100: 188-197

Clarke, A., Rodhouse, P. G., Holmes, L. H., Pascoe, P. L. (1989). Growth rate and nucleic acid ratio in cultured cuttlefish Sepia officinalis (Mollusca: Cephalopoda). J. exp. mar. Biol. Ecol. 133: 229-240

Clemmesen, C. (1987). Laboratory studies on RNA/DNA ratios of starved and fed herring (Clupea harengus) and turbot (Scophthalmus maximus) larvae. J. Cons. int. Explor. Mer 43: 122-128

Clemmesen, C. (1988). A RNA and DNA fluorescence technique to evaluate the nutritional condition of individual marine fish larvae. Meeresforschung 32: 134-143

Clemmesen, C. (1989). RNA/DNA ratios of laboratory-reared and wild herring larvae determined with a highly sensitive fluorescence method. J. Fish. Biol. 35(Suppl. A): 331-333

Clemmesen-Bockelmann, C. (1992). Das RNA/DNA Verhältnis als Indikator für den Ernährungszustand von Fischlarven. Ph.D. thesis, University of Hamburg

Dagg, M. J., Littlepage, J. L. (1972). Relationships between growth rate and RNA, DNA, protein and dry weight in Artemıa salina and Euchaeta elongata. Mar. Biol. 17: $162-170$

DeBevoise, A. E., Taghon, G. L. (1988). RNA:DNA ratios of the hydrothermal-vent vestimentiferans Ridgeia piscesae and $R$. phaophiale indicate variations in growth rates over small spatial scales. Mar. Biol. 97: 421-426

DeFlaun, M. F., Paul, J. H., Davis, D. (1986). Simplified method for dissolved DNA determınations in aquatic environments. Appl environ. Microbiol. 52(4): 654-659

Dortch, Q. Roberts, T. L., Clayton, J. R. Jr, Ahmed, S. I. (1983). RNA/DNA ratios and DNA concentrations as indicators of growth rate in planktonic marine organisms. Mar Ecol. Prog. Ser. 13: 61-71 
Fukuda, M., Nakano, H., Yamamoto, K. (1986). Biochemical changes in Pacific herring during early developmental stages. Hokkaido Daigaku Fac. Fish Bull. 37: 30-37

Guiltbault, G. G. (1973). Practical fluorescence. Marcel Dekker, New York

Karsten, U., Wollenberger, A. (1972). Determination of DNA and RNA in homogenized cells and tissues by surface fluorometry. Anal. Biochem. 46: 135-148

Karsten, U., Wollenberger, A. (1977). Improvements in the ethidium bromide method for direct fluorometric estimation of DNA and RNA in cell and tissue homogenates. Anal. Biochem. 77: 464-470

Labarca, C., Paigen, K. (1980). A simple, rapid, and sensitive DNA assay procedure. Anal. Biochem. 102: 344-352

LePecq, J.-B., Paoletti, C. (1966). A new fluorometric method for RNA and DNA determination. Anal. Biochem. 17: $100-107$

Maniatis, T., Fritsch, E. F., Sambrook, J. (1982). Molecular cloning. A laboratory manual. Cold Spring Harbour Laboratory publications, New York

Martin, F. D., Wright, D. A., Means, J. C., Setzler-Hamilton, E. F. (1985). Importance of food supply to nutritional state of larval striped bass in the Potomac river estuary. Trans. Amer. Fish. Soc. 114: 137-145

McGurk, M. D., Kusser, W. C. (1992). Comparison of three methods of measuring RNA and DNA concentrations of individual pacific herring, Clupea pallasi, larvae. Can. J. Fish. Aquat. Sci. 49: 967-974

Mordy, C. W., Carlson, D. J. (1991). An evaluation of fluorescence techniques for measuring DNA and RNA in marine microorganisms. Mar. Ecol. Prog. Ser. 73: 283-293

Ota, A. Y., Landry, M. R. (1984). Nucleic acids as growth rate indicators for early developmental stages of Calanus pacificus Brodsky. J. exp. mar. Biol. Ecol. 80: 147-160

This article was submitted to the editor
Prasad, A. S., DuMouchelle, E., Koniuch, D., Oberleas, D. (1972). A simple fluorometric method for the determination of RNA and DNA in tissues. J. Lab. Clin. Med. 80: $598-602$

Raae, A. J., Opstad, I., Kvenseth, P., Walther, B. T (1988). RNA, DNA and protein during early development in feeding and starved cod (Gadus morhua L.) larvae. Aquaculture 73: 247-259

Regnault, M., Luquet, P. (1974). Study by evolution of nucleic acid content of prepuberal growth in the shrimp. Crangon vulgaris. Mar. Biol. 25: 291-298

Robinson, S. M. C., Ware, D. M. (1988). Ontogenetic development of growth rates of larval Pacific herring, Clupea harengus pallasi, measured with RNA-DNA ratios in the Strait of Georgia, British Columbia. Can. J. Fish. Aquat. Sci. 45: 1422-1429

Ueberschär, B., Clemmesen, C. (1992). A comparison of the nutritional condition of herring larvae as determined by two biochemical methods - tryptic enzyme activity and RNA/DNA ratio measurements. ICES J. mar. Sci. 49: 245-249

Wang, S. Y., Stickle, W. B. (1986). Changes in nucleic acid concentration with starvation in the blue crab Callinectes sapidus Rathbun. J. Crust. Biol. 6: 49-56

Weisblum, B., Haenssler, E. (1974). Fluorometric properties of the bisbenzimidazole derivative Hoechst 33258, a fluorescent probe specific for AT concentration in chromosomal DNA. Chromosoma 46: 255-260

Westerman, M. E., Holt, G. J. (1988). The RNA-DNA ratio: measurement of nucleic acids in larval Sciaenops ocellatus. Contr. mar. Sci. 30 (Suppl.): 117-124

Wright, D. A., Hetzel, E. W. (1985). Use of RNA/DNA ratios as an indicator of nutritional stress in the American oyster Crassostrea virginica. Mar. Ecol. Prog. Ser. 25: 199-206

Manuscript first received: December 8, 1992

Revised version accepted: July 12, 1993 